\title{
Teaching english to very young learners through authentic communicative performances *
}

\author{
Cómo enseñar inglés a aprendices muy jóvenes por \\ medio de desempeños auténticos comunicativos
}

\author{
Diana Carolina Guevara \\ Programa de segunda lengua \\ Universidad Nacional de Colombia \\ Bogotá-Colombia \\ E-mail: diacarolinagn@hotmail.com \\ Claudia Lucia Ordoñez \\ Licenciatura en Filologia e Idiomas \\ Universidad Nacional de Colombia \\ Bogotá-Colombia \\ E-mail: clordonezo@unal.edu.co
}

Received: 29 - Aug - 11 / Accepted: 24 - Apr -12

\begin{abstract}
We present here the results for the kindergarten level of a qualitative research study on the impact of a curriculum connecting learning events in Spanish and English in authentic communicative performances. The school in the study was a private institution in a mid-sized Colombian city. The curriculum is based on communicative and constructivist principles and presents the learning events as communicative authentic performances. We describe the performances that the kindergarten teachers developed based on the curriculum, how they achieved authenticity in them, and their impact on the students' attitude towards the English class and on their learning. We analyzed four teacher interviews and four class observations done over a year, plus two more class recordings made independently by the teachers. They reveal that teachers used a variety of games, especially role-playing games developed from ideas from the children, reading of stories, and songs and that the students became enthusiastic and active and improved their oral skills considerably.
\end{abstract}

Key words: constructivism in English teaching, authentic communicative performances, education for bilingualism, preschool English as a foreign language.

\section{Resumen}

Presentamos los resultados en el nivel de Kindergarten de una investigación cualitativa sobre el impacto de la aplicación de un currículo bilingüe que conecta aprendizajes en español e inglés en un colegio bilingüe de una ciudad intermedia colombiana. El currículo se basa en principios constructivistas y comunicativos y presenta los contenidos de aprendizaje en forma de desempeños auténticos de comunicación. Describimos los desempeños que crearon las maestras con base en el currículo, las formas como lograron su autenticidad y el impacto que tuvieron en la actitud de los estudiantes hacia la clase de inglés y en su aprendizaje. Analizamos 4 entrevistas a los maestros participantes y 4 videos de clases tomados a lo largo de un año escolar, más 2 videos de clases que tomaron las maestras independientemente. Los datos revelan que las docentes usaron una diversidad de juegos, sobre todo juegos de rol desarrollados a partir de ideas de los niños, lectura de cuentos y trabajo con canciones y que los estudiantes se mostraron entusiastas y activos en las clases y avanzaron considerablemente en sus habilidades de producción oral.

Palabras clave: constructivismo en enseñanza de inglés, desempeño auténtico comunicativo, educación para el bilingüismo, inglés como lengua extranjera en preescolar. 


\section{Résumé}

Nous présentons les résultats dans le niveau de Maternel d'une recherche qualitative sur l'impact de l'application d'un curriculum bilingue qui fait des liens entre des apprentissages en espagnol et en anglais dans une école bilingue d'une ville intermédiaire colombienne. Le curriculum est fondé sur des principes constructivistes et communicatifs. Nous décrivons les objectifs fixés par les institutrices sur la base du programme d'études, les manières au moyen desquelles elles ont parvenu à leur donner de l'authenticité et l'impact sur l'attitude des étudiants vis-à-vis du cours d'anglais et sur leur apprentissage. Nous avons analysé 4 entretiens avec les instituteurs qui y ont participé et 4 cassettes vidéo des cours, prises pendant une année scolaire, ainsi qu'autres 2 cassettes vidéo prises par les institutrices d'une manière indépendante. Les données montrent que les enseignantes ont fait appel à divers jeux, surtout des jeux de rôle à partir des idées des enfants, des lectures d'histoires et un travail avec des chansons, et que les étudiants se sont montrés enthousiastes et actifs pendant les cours et qu'ils ont fait d'énormes progrès dans leurs compétences de production orale.

Mots clés: constructivisme dans l'enseignement de l'anglais, performance communicative authentique, éducation pour le bilinguisme, enseignement de l'anglais à des enfants petits, anglais comme langue étrangère en maternel.

\section{Resumo}

Apresentamos os resultados no nível de Kindergarten de uma pesquisa qualitativa sobre o impacto da aplicação de um currículo bilíngue que conecta aprendizagens em espanhol e inglês em um colégio bilíngue de uma cidade intermédia colombiana. O currículo se baseia em princípios construtivistas e comunicativos e apresenta os conteúdos de aprendizagem em forma de desempenhos autênticos de comunicação. Descrevemos os desempenhos que criaram as professoras com base no currículo, as formas como conseguiram sua autenticidade e o impacto que tiveram na atitude dos estudantes em relação à classe de inglês e na sua aprendizagem. Analisamos 4 entrevistas aos professores participantes e 4 vídeos de classes tomados ao longo de um ano escolar, mais 2 vídeos de classes que tomaram as professoras independentemente. Os dados revelam que as docentes usaram uma diversidade de jogos, principalmente jogos de papel desenvolvidos a partir de ideias das crianças, leitura de contos e trabalho com canções e que os estudantes se mostraram entusiastas e ativos nas classes e avançaram consideravelmente nas suas habilidades de produção oral.

Palavras chave: construtivismo em ensino de inglês, desempenho autêntico comunicativo, educação para o bilinguismo, ensino de inglês a crianças pequenas, inglês como língua estrangeira em pré-primária.

* The article is one of the products of the research project "Evaluación de la puesta en práctica y la efectividad de un currículo de español e inglés en el Colegio San Bonifacio de las Lanzas" The main objective of the project was to implement a new bilingual (Spanish-English) curriculum and to evaluate its impact in the language learning enviroments and the learning of theachers and students. Colegio San Bonifacio de las Lanzas and Universidad Nacional de Colombia; convocatoria Orlando Fals Borda, 2009. Project code: 10533. 


\section{Introduction}

Arguing for the increasing need to use English in international business and education, the Colombian Ministry of Education has made learning English a national educational policy (MEN, 2006). This policy forces all schools to implement institutional practices that have been characteristic of bilingual schools in the country for years, like teaching the foreign language from preschool. In this present reality, the search for effective ways to teach an unfamiliar language to young children has become a priority, and it constitutes a challenge in diverse Colombian sociolinguistic contexts, where the use of a second international language is not necessary and, therefore, not naturally stimulated.

Even though we believe in the importance of becoming bilingual (not necessarily in English), we do not endorse the teaching of a foreign language to very young children in our Colombian contexts. We would consider formalized learning of the foreign language quite later than preschool, to allow children to first develop Spanish and other first languages solidly and to complete the first stages of the reading and writing process in Spanish before starting with a foreign language. In Colombia, there are mostly Spanish monolingual sociolinguistic contexts, where the use of an international language other than Spanish has no immediate reality for learners. It can disrupt the initial development of Spanish and other first languages in school, and thus is not desirable and possibly even counterproductive (Ordóñez, 2004; 2005). However, in the specific bilingual school in this article, where we were hired as consultants to help improve the students' level of English, it was not possible to change the practice of introducing the foreign language at a very early age. Bilingual education has convinced teachers and parents that it is necessary to start early, and the arguments against the necessity to do this are, unfortunately, not widely known (Marinova-Todd,
Marshall, \& Snow, 2000). Therefore, we decided to implement a curriculum that would ensure the development of Spanish to high skill levels and would connect this development to the learning of English following two rules: developments in Spanish came before anything was done in English and reading and writing in English were not introduced before third grade. At the same time, we decided to trust the ability of the children to learn anything they were interested and able to participate in.

\section{Bilingual Education in Colombia}

Two facts about language acquisition are consistently supported in research. First, everyone can learn one or several languages; and second, the success of this learning depends on the real need or wish to use the new language(s) in authentic communication (Snow, 2007). This is because what motivates and promotes the learning of language is the social need and the pragmatic demands of communication, that is, the characteristics, relationships, and purposes of those who communicate and the contextual conditions in which they do so (Ninio and Snow, 1996). This is why teaching and learning a second language in mostly monolingual sociolinguistic contexts is a huge challenge. As we do not need to use English to function in society, it is especially difficult for us to motivate our children and adolescents to learn it.

In Colombia's limited experience with school bilingualism in international languages, the institutions perceived as most successful are the bilingual schools. These are mostly elite private schools in large cities, which have adopted bilingual education models developed for contexts alien to ours (Ordóñez, 2008). Many follow the programs and practices of Canadian immersion and even programs, policies, and accreditation systems used by and for monolingual schools in 
Europe or the United States (De Mejía, Ordóñez and Fonseca, 2006). But they also follow common sense: if the foreign language does not occur naturally in our social context, creating the need for it in school is logical. To do so they set up artificial environments in which the foreign language of interest becomes necessary for communication and academic success, through four basic actions: the introduction of the foreign language at the earliest possible age (usually in preschool and often in partial or total immersion), the instruction of academic subjects in the foreign language, the hiring of native foreign language teachers, and the requirement that everyone in school speaks in the foreign language, both in and outside of classes.

But the very little research done in bilingual schools reveals that their administrators can easily ignore important facts of language acquisition. Concern for the lack of use of the foreign language in the immediate social context causes many bilingual schools to focus on it at the expense of Spanish, the development of which they take for granted (De Mejía, Ordóñez, and Fonseca, 2006). Some of this research has even produced evidence of impoverishment of some communicative skills in Spanish and a strong influence of the rhetorical characteristics of English on the Spanish oral narratives of students from these schools, when compared to those of students from Spanish monolingual schools (Ordóñez, 2000; 2004; 2005). Although there is no evidence from research of bilinguals exhibiting the same skills of two monolinguals, and it is not expected that they do so, a considerable reduction of skills in the first language is not justifiable in a monolingual sociolinguistic context.

The goal of bilingualism cannot override a central fact of language acquisition: After 4 or 5 years of age, the main stimulus for the development of language is the school experience. This is because entering school creates for the child the need to communicate with a variety of new people, in a variety of new communicative situations, and in the context of a variety of new topics and discourse types associated with them. Additionally, reading and writing start formally in school, and they become the largest possible source of linguistic expansion (Barriga-Villanueva, 2002; 2003). This is true for the foreign language when its development is a school goal, but it is first true for the first language, the development of which should not be neglected in school.

In addition to this, children born monolingual can become bilingual in school, but they will be consecutive bilinguals, having acquired a lot of their first language before entering school. This means that they will naturally use their knowledge of the first language to learn the second one and will need to be able to consciously recognize differences between the two. Schools which commit to the goal of bilingualism in our monolingual context need to find ways to respond to the needs not only of foreign language learning, but of sophisticated development in the first language.

\section{School Bilingualism in Crisis}

The difficulty posed by monolingual sociolinguistic contexts for the learning of English varies in intensity in the very different circumstances in which communities live in a country as diverse as Colombia. For example, it is a little easier in our big cities to find English speaking people, books in English, and places where English is in use, in touristic and commercial activities, for example. But in our smaller cities, the use of English is farther away from the daily life of children and youngsters. However, many schools in mediumsized and small cities have followed the model of bilingual institutions, without considering the extra difficulty posed by the socio-linguistic contexts in 
which their students socialize. The school where the present research was conducted is located in a medium-sized Colombian city, so we felt it illustrated this problem well.

The school had struggled for around 15 years to produce bilingual individuals by undertaking the above-mentioned actions, with poor results. The students did not speak English easily, naturally, or willingly, they often showed actual resistance to using it, and instead of English they used something like Spanish with English words. Among the possible reasons for this situation, the school administrators mentioned the level of English and of pedagogic effectiveness of their teachers, the lack of foreign teachers, and their inability to put English into use in enough classes, school events, and places in the institution. Nevertheless, they were open to their consultants' explanations, based on the attitude that the students had regarding the absence of a need for the use of English in their lives, and to trying curricular ideas not typical of the model Colombian bilingual school.

\section{The New Curriculum: Multiple Connections}

The consultants developed the curriculum with a group of some of the English and Spanish teachers chosen by the school and the coordinators of the two language areas. It was critical to connect the work of the two language departments to achieve the connections we wanted to produce in the development of the children's linguistic skills in Spanish and English. For eight months the group discussed language development in the school, the curriculum in use, and a few theoretical documents that illuminated new possibilities for achieving bilingualism. They also explored the concept of authentic performances (Ordónez, 2010a) and tried designing some suited for the real communicative contexts in which their students moved in their lives. At the end of this year, the collective experience was made into a new curriculum with the following characteristics:

- It applies constructivist principles of human learning, relating to authentic action for learning connecting to communicative linguistic theory to produce a curriculum focused on "authentic communicative performances."

- It is actually bilingual, due to the free use of Spanish to help children learn English and the application of theory on first language acquisition in connection to the importance given in constructivism to previous knowledge in the building of new a one.

- It covers three contexts of language development: that of daily communication and communication through the mass media, the communication necessary when approaching knowledge in different academic disciplines, and artistic and cultural expression.

The characteristics of the curriculum are consistent with four basic constructivist principles taken from the work of different researchers who have contributed to the complex construct that is, today, this description of human learning. The first one points to the fact that learning occurs when doing things. Piaget (1970) refers to manipulating elements in the environment; Vygotsky (1978) to social actions with others with different levels of cognitive development and knowledge; Perkins (1998) to performances of understanding; and Dewey (1945) and the theory of situated cognition (Brown, Collins yand Duguid, 1989; Díaz Barriga, 2003) to action as it occurs authentically in life. Authentic activity with language is always the representation, transmission, and purposeful use of meaning in communication among interlocutors or writers and readers. Hence the curriculum is composed of authentic communicative performances, 
communicative actions or processes performed in specific contexts and with specific purposes by people who use their knowledge in their daily or professional life.

Applied Linguistics enables us to identify authentic communicative performances in the real world, on the basis of the pragmatic conditions that define communicative acts: the characteristics of the sender of the message, the position from which he/she sends it and his/her purpose, the characteristics of the receiver, the relationships between sender and receiver, and the context in which communication occurs. These conditions have been specified by researchers during more than 30 years of development and use of the communicative approach to language analysis (Widdowson, 1978; Van Lier, 2005).

The curriculum, then, focused on authenticity. Its implementation depended completely on the teachers' ability to analyze their own and others' real-life communicative actions, processes, and products and turn them into learning situations. They could enact the communicative performances in their classrooms or take the students to environments where they would naturally occur. Authenticity for specific groups of students was further supported when performances were related to the students' contexts and interests; when the students themselves participated in decision-making about what to learn, what to do to learn, and how to do it; and when communicating required the use of different sources of information, knowledge from different disciplines and of different types, and interactions with multiple others.

The recognition of work with others as an authentic feature of real life performance is reinforced by the second constructivist principle. Socio-cultural in nature and initially established by Vygotsky (1978), it recognizes interaction with others as basic for individual learning. As a result, teaching and learning on the basis of this curriculum are highly based on collaborative work.

The third constructivist principle indicates that all learning occurs naturally as process (Piaget, 1970). For this reason, the curriculum indicates starting points for work on specific communicative performances, but not ending points. After a communicative performance and its associated language are introduced, they appear and re-appear repeatedly in different contexts. As a result, the same or very similar performances also appear in different grades, to be done in increasingly complex ways according to the age of the students and their accumulated language repertoire, which is maintained in permanent use. This corresponds to Dewey's description of a cyclical curriculum (1948), whose purpose is not to differentiate learning periods or school grades on the basis of content, but to guide learning processes.

The fourth constructivist principle contributes to this cyclical nature of the curriculum, as it states that all new learning is built on knowledge previously constructed (Piaget, 1970; Ausubel, 1968). The application of this principle requires the curriculum to constantly connect the performances and language already used to the new performances and language presented. It also supports building the skills in the foreign language on the basis of those in the first language, a feature that defines the curriculum as bilingual.

The curriculum is bilingual, then, because all communicative performances occur first in Spanish and then they serve as support for similar ones in English. Spanish and English teachers, then, have to work together in planning and designing instruction. In many occasions, starting from the students' interests in really communicative, authentic activities that they cared about in Spanish, the curriculum allows 
teachers working in collaboration to motivate the students to do them in English, too. Thus the two languages end up being used for similar communicative purposes and bilingually in the same performances whenever possible and natural, with the support of teachers from both areas (e.g. looking for and using information in bibliographic research; interviewing speakers of both languages as informants in journalistic, personal, or empirical research; developing bilingual radio and TV shows, news programs and newspapers). This also allows teachers to complement each other's knowledge when the students need help in comparing their two languages to understand how they work similarly or differently.

Finally, the three contexts for communicative development covered in the curriculum - daily life and the media, academic, and aesthetic-cultural communication - are not unknown to language teachers. However, one or more of them can be forgotten or at least neglected in their classes. The curriculum consistently reminds teachers to include communicative performances in the three contexts and to connect them whenever possible.

\section{The Study}

The research, the partial results of which we present here, began at the end of 2008 with financial support from the National University and in agreement with the school. It started with trying out of a few performances planned by the design group and some others created by the teachers. The first data come from information provided by both Spanish and English teachers about these piloting efforts. In 2009 the previous Spanish and English curricula, based mostly on formal specific achievements ("logros"), stopped being used and the new bilingual one was adopted in the whole school; the study advanced as a parallel activity to the first year of implementation, 2009.

\section{Method}

The research study is qualitative and was designed to evaluate the impact of the curriculum on the learning of students and teachers in both Spanish and English (Ordóñez, 2010b; 2011). A qualitative methodology was consistent with the nature of the changes that the curriculum was intended to produce initially, which had to be apparent in what happened inside the language learning classrooms, in the actual performance of teachers and students, and through their opinions and experiences. The impact of the curriculum on the first and foreign language development of the students, the final goal of the whole project, would need to be evaluated quantitatively through standardized tests after a longer period of time. The part of the study we report on here focuses on the learning of English of the youngest students in the school and answers the following research questions:

- What communicative performances did teachers carry out in English with kindergarten students and how was authenticity achieved in them?

- How did the implementation of the curriculum based on authentic performances influence the children's attitude towards the English class?

- How did the curriculum based on authentic performances influence the children's learning of English?

We focus our present report on two kindergarten groups of 25 6-7 year olds each, taught by Colombian teachers. They were not formally trained as English teachers: one was a professional in International Business and the other a professional in Children's Education and Psychology. Data consist of in-depth, semistructured interviews conducted with the teachers and videos of all the English classes they taught on Thursdays and Fridays on four occasions during the academic year (December/February, 
April, May, and September). We also used two videos the teachers made independently in their classes to record performances devised by the students and which were considered especially interesting.

We described what the students were doing in the performances in the videos and transcribed the communicative interchanges recorded and the interviews; then we did discourse analysis on the transcriptions, looking for specific information to answer the research questions: characteristics of the communicative performances used in the classes and evidence of the children's attitudes and learning. To determine final results, we triangulated findings from the interviews and the class observations.

\section{Results}

As this partial report focuses on work in English, there will not be much information about what was happening in Spanish that supported the English learning that will be shown. In spite of this, the following words by the Spanish teacher at the preschool level constitute a good indication of what happened throughout the year:

\begin{abstract}
[Before] I was not working with the English teacher ... for many reasons. But now we reread the curriculum and there I really understood the importance of working with the English teachers, because the children assimilate English on the basis of their mother tongue ... Now we do meet... we have improved team work... We try to identify the language [we need to teach]; we plan a performance together... For the children it has made it easier to understand many things more in English. (Preschool Spanish teacher interview, Sept.).
\end{abstract}

The data will also show our participant English teachers letting students use Spanish when necessary in the development of different communicative performances to get to the
English they were interested in, and we will point to any other connections to Spanish development when possible.

The teachers planned the performances for their groups together, based on the principles and the guide included in the curriculum and provided by the consultants in the few meetings organized during the year, every time data were collected. Both teachers' testimonies and researchers' observations showed that the performances used were effectively adapted to the students' age and that communicative authenticity was achieved by using the students' ideas and interests. Due to their young age and short life experience and to the lack of authentic use of English in their lives, most performances were role play games about diverse topics the students proposed, which allowed for the introduction and practice of a varied repertoire of language they were interested in learning. Reading stories and learning and interpreting songs were equally successful performances.

Working communicatively helped the children develop positive attitudes towards the foreign language class. They produced English with real purposes and participated actively in pedagogical decision-making, which translated into effective learning and cheer enjoyment. According to their teachers, as a result of all this the kids improved their oral skills greatly and learned how to interact with English-speaking people outside of class. In what follows we present evidence for these results.

\section{The Performances}

On the basis of its integral connection between English and Spanish development at the preschool and early primary levels, the curriculum dictated that communicative activity had to be only oral from preschool up to the third grade, to allow the children to advance in 
their Spanish literacy process before a different reading system was introduced. Games were the main source of English oral performances at the Kindergarten level, role play the preferred kind. One of the teachers stated that performances based on games made leaning more real and enjoyable for students:

I do think that the use [of the new curriculum] has been an enriching experience because I can see the results in the children; I can see how they enjoy the class... one tries to make things more real and children also make it more realistic... a game is very real for them; and even though the game is fictitious, they know what they are doing and want to do it well. (T1 interview, Sept.).

Besides being interesting for children, role play allowed teachers to support learning in environments close to reality: "We mainly focus in role play, which is what they like the most. We are working on all professions, ....and children love it. They wear costumes and come happy to class to perform the characters' actions." (T2, interview Sept.).

Different professions proposed by the children were the most popular topics for performances, especially those related to their parents' professions. Children portrayed people working at hospitals, shops, hotels, and restaurants. As can be seen below, the students worked on a performance occurring in a doctor's office. They organized themselves into groups and in each there was a doctor, a patient, a nurse and a receptionist.

\footnotetext{
Patient: Good morning

Receptionist: Good morning. How can I help you?

Patient: I need a doctor

Receptionist: Yes, wait a minute. What

is

your telephone number?

Patient: $\quad 289924$
}

$\begin{array}{ll}\begin{array}{ll}\text { Receptionist: } \\ \text { Patient: }\end{array} & \text { Where do you live? } \\ \text { In Camino. } \\ \text { Patient: } & \text { Good morning. } \\ \text { Nurse: } & \text { Good morning. } \\ \text { Patient: } & \text { My baby is sick } \\ \text { Nurse: } & \text { Pass [sic.], please } \\ \text {.. } & \text { Good morning, how can I } \\ \text { Doctor: } & \text { help you? } \\ & \text { Good morning, my baby is } \\ \text { Patient: } & \text { sick. } \\ & \text { Let me see (doctor checks } \\ \text { Doctor: } & \text { the patient) } \\ & \text { Thank you } \\ \text { Patient: } & \text { You are welcome. } \\ \text { Doctor: } & \text { (T1's video, April) }\end{array}$

The profession of a chef was another one simulated in role play. Students prepared to present recipes they liked and recorded a video of a cooking TV show for their parents. The students got into groups of three: the show host/hostess, the chef, and his/her assistant. The host showed the ingredients and materials, the chef cooked, and the assistant helped the chef and presented de dish.

Est1: Good morning, my name is $X X X X$, I am six years old. My recipe is 'Mickey Mouse eggs.' The ingredients are ketchup, salt, and four eggs. The materials are a plate, a knife, and a spoon. Now, the chef.

Est2: Good morning, my name is $X X X X$, I am six years old. My recipe is 'Mickey Mouse eggs.' Step number one: put the eggs in water. Step number two: cut the eggs in small pieces. Step number three: decorate the Mickey Mouse eggs with the ketchup. Step number four: eat the Mickey Mouse eggs and enjoy them.

P: Let's suppose this is the ketchup. So, do it...show them.

Est2: ...And enjoy them.

$\mathrm{P}$ : Who is next? 
Est3: This is a good way to start the morning. Now it is the opportunity for a wonderful chef to cook something for us. (T2's video, Sept.)

Another interesting game for the children had to do with descriptions. Looking for authentic performances to work on descriptions, teachers used two types of games: interactive virtual games found on the Internet which allowed children to identify people's physical features and design different characters with specific features, and adapted games based on already existing ones, such as "Guess Who?" Here a student produced a physical description orally for another to identify the person. In our April visit, students were playing "Guess Who?" in pairs, with boards they had made with pictures of people.

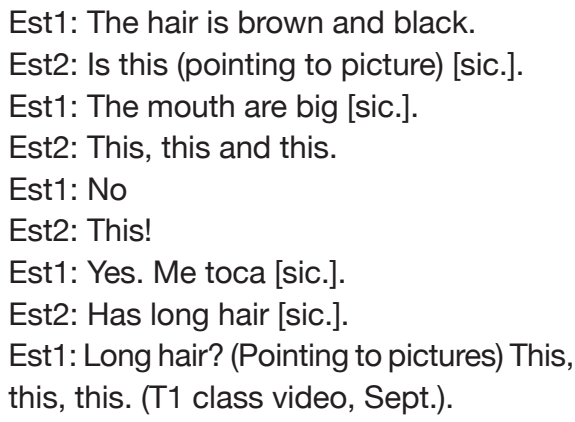

Besides games, the teachers used story reading and songs as authentic communicative performances. Story reading was called "Story Time". One teacher indicated that "...they [children] always ask for Story Time because they like it; when they ask for it I always do it." (T1 interview, April). English reading was mainly done by teachers using big books with colorful images, frequently making children participate by saying words from the story. This activity became a constituent part of every class. In our visit in February, the teacher was reading a big book and the students seemed very enthusiastic and participated actively. They learned new language by working with meaning in the context of the story and connecting what was said in the book and the pictures they saw.

Ests: Ah, yes!

P: (Showing the book) Quick is fast, fast. It's a cricket; do you know what a cricket is?

Ests: Yes.

P: It's fast, fast.

Est19: ¿Un saltamontes?

$\mathrm{P}$ : What is fast? Quick. It's the same [as] quick, everybody. Quick, quick, quick. Fast, fast, fast. Ok... I want to show you this first and then you can read and see the images... This is a boy. What do you see here? The boy is saying: 'I am as fast as a cricket.' What is a cricket? 'I am as fast as a cricket.' This is a cricket. Everybody fast, fast, fast or quick; it's the same. I am as slow as a snail, slow, slow, slow like a snail, do you see the snail? (T2 class video, February)

Learning and singing songs were constituent performances in most of the classes as well. In addition to enjoying singing, little children produced a lot of language in an easy and amusing way while practicing the songs. One of the teachers enthusiastically said that children loved it (T1 interview, Sept.).

\section{Authenticity}

Regarding the authenticity of the performances, teachers constantly expressed the difficulties they had to achieving it. However, through role play they made children portray characters and simulate activities from real life, thus learning the language used in real communicative situations. Furthermore, teachers developed performances from children's ideas: the children were allowed to use Spanish to contribute ideas from which to choose and plan performances and to help in deciding on 
the materials and the resources to be used. In doing this, they also practiced communicating in Spanish before they tried it in English. Children's active participation was constantly stimulated by the teachers, and this in turn led the kids to work autonomously in their classes: “...Children lead you to authenticity ...No matter how much I plan, I have never carried out a performance as I planned it. Ideas are always coming up [from children] along the path." (T1 interview, Sept.).

The students also helped solving problems that emerged when putting the performances into practice. For example, students gave ideas to solve some difficulties in a performance about professions in a hotel:

Today we were playing 'hotel' and a student said [in Spanish] 'no, it doesn't look like a hotel, it is horrible.' So another student turned and answered: 'Oh! Remember that we are children and this is a game; everything is fake'. They... solve almost everything. I said 'I don't have many materials to make the hotel,' and they said 'Hey! Look, this is the food... and here is the pool,' and they made the pool... and the restaurant themselves [with desks and bags]... They organized everything and created a great space and also respected it: 'Hey, no! That's the pool, this is the...' I mean, in the classroom we have had everything!" (T1 interview, May).

Besides letting children participate, another way to achieve authenticity was establishing connections between performances and children's real contexts, mainly their daily activities out of class or activities organized in the school: “... They like it [the chef role play] because they say that at home they help their parents prepare food: they open the fridge themselves and take things out; they prepare [simple things like] a chocolate drink... ..." (T2 interview, Sept.).
Other authentic activities came simply from the children's real life and what they felt like sharing with their classmates about themselves and their families. In the following example, children bring information to class in Spanish, after obtaining it from people outside of the classroom:

We had a [performance] called "When I was a baby"... First they [wanted to do] an interview with their parents asking them, obviously in Spanish, what they did when they were babies, if they cried a lot, what they ate, things like that. Then they said that in Spanish and we helped them translate it. Then they could say: "When I was a baby, I used to eat baby food"... They brought pictures of [themselves] when they were babies [and] then [said] "When I was a baby..." showing the picture. And then they talked about a classmate: "He used to like this, his favorite program was this". (T1 interview, May)

Finally, teachers achieved authenticity by promoting interaction and cooperation between students. In the following excerpt from a class observation, students are using some pictures they drew themselves, representing their parents' professions. The pictures are displayed on a wall and a student has to choose one and ask the student who drew the picture information about his/her parents' professions:

Est21: Whose picture is this?

Est22: Mine

Est21: What's your name?

Est22: My name is XXXX.

Est21: My mother's

P: Your mother's

Est21: Your mother's name?

Est22: Is XXXX

Est21: Your mother's name is $X X X X$; she is school principal; she works school principal [sic.] (T2 class visit, April) 


\section{The Consequences of Authenticity}

As a result of all this, students seemed quite happy to use the foreign language.

To say the truth, it has been a vast change from last year to the present, and children... are very motivated in the English class. [It] is something enjoyable for them... It is no longer as it was last year: I arrived... and [the children went] 'Oh, English!'... not because of me but because there were many worksheets and no fun. Children have liked this more... and then... I motivate them to speak in English and they are doing it... (T2 interview, May).

The children's motivation was also revealed in students' spontaneous participation in class. In the visit we did in April, a student started to tell us about himself without being asked by the teacher or another adult. The child told us about him, his family, and things he liked: "...my name is XXXX, my father's name is XXXX, he is a engineer [sic.]; he works in the office. My mother's name is XXXX, she is engineer [sic.], she works in the office. Eh... I practice soccer; I live in XXXX, I like eat spaghetti and fish [sic.]." (T2class video, April).

There were other positive consequences of the different ways in which teachers achieved authenticity. One argued, for example, that the connection between topics and the reality of the use of English influenced students' learning and attitudes positively. She explained that when learning had a real communicative purpose and happened from students' activity, they enjoyed the process and learned more effectively:

I definitely think that children do not learn if one does something [one thinks] great but it is not real. For instance, I make a sculpture and I exhibit it; I make a picture and I give it to children from a different class; I learn a song and I sing it in front of other students. I mean, the need to do it well because it is a project, because my name is on the line, that is what truly motivates them... They want to be the best and you have to create the space to help them achieve their goal. So, how do we do this? By doing useful things that they can show and give to others out of the class. I have realized that they learn by doing things that are really meaningful for them. (T1 interview, Sept.).

Finally teachers referred to a change of roles related to the students getting directly involved in their class, as the teacher stopped playing the sole owner of the knowledge.

We don't sit facing the board and listen to the teacher talk, but students are the ones who do the class themselves; they are the ones who speak, propose, and demand. This motivates them, that they participate totally in the activities and that most of the things they propose are carried out, because we are looking for what they like (T2 interview Sept.).

\section{And, of Course, More English}

From all this performance and authenticity, the children acquired a wide repertoire of oral language. Following the curriculum directive of only oral communicative activity, teachers noted an important improvement in students' oral expression from the beginning:

... [Before ]there used to be a lot of desk work... Everything was focused on listening. You told the children something and they understood, but they couldn't express anything... So you thought, 'If they can listen to me and understand, why can't they talk?' And no, it didn't happen... [or] maybe in the third or fourth year... [they uttered] very simple things. But now I realize that children can produce many things and can interact in a situation in English and handle it, obviously 
in appropriate terms for their age. (T1 interview April)

The data showed that students produced a lot of language orally and learned to communicate in different daily situations using accurate structures and vocabulary. An important part of this language learned, highlighted by the teachers, was the ability to ask questions and give answers to exchange information:

They already communicate with new people... ask them things like 'where do you live; what do you like... and about what they like.' They already follow and give instructions, compare... Listening abilities have developed greatly... They ask questions and give answers; they didn't do that last year... That is what has surprised me. I like it very much! (T2 interview Sept.).

Performances practiced included asking and answering questions when going to the supermarket or to the doctor and giving and following instructions in cooking. The teachers also noted that as they worked with authentic communicative performances and allowed Spanish to be used, students asked for even more language than they had planned for.

They are asking many things: 'teacher, how do you say xxx?'... Obviously at the beginning it was very difficult because they said: 'teacher, how do you say go to the bathroom and come back? [in Spanish]' ... They got confused. Now they try to think 'How can I say this using what I know and what I don't,' and then 'teacher, how do you say I want to go to 'la cocina' (the kitchen)? [just saying one word in Spanish]" (T1 interview, April).

\section{Conclusions}

Throughout the year, teachers expressed difficulties in finding and planning performances which were actually authentic for their young students. This is natural given the lack of need for English in real communication around the kids. Nevertheless, teachers used different types of games, songs and story-telling for their learning. Students could actively participate not only in the performances themselves but in the selection of subjects and the decisions on how they were to be developed. Apart from involving children, teachers made these performances authentic by using real language and adapting it to the students' context and interests.

Active participation of students, the freedom to use Spanish, and the use of their interests in planning performances allowed them to enjoy the English class and be motivated to actually use English, which made foreign language learning more effective. The implementation of authentic performances led to considerable improvement of oral skills, represented mainly in the exchange of information through questions and answers, following instructions, interpreting songs, and talking about stories. Through all this communication, vocabulary and grammar were used in context and, so, with meaning and without actual specific lessons on them. This is an important achievement, since the use of communicative teaching in foreign language classes often means forgetting to teach form or taking it as an objective secondary to communication.

In a monolingual context like ours, where the use of a second language is not really meaningful for children, it is not necessary to learn it from an early age; it is more important to allow for the development of the mother tongue and richly stimulate it. However, if it is really considered important to learn a second language during childhood, it is necessary to encourage real communication from the start and to use students' participation in pedagogical decisionmaking. Taking into account their interests and 
ideas is essential for them to learn that the foreign language can be useful to communicate and that this can be interesting and enjoyable.

It is also essential that children always understand what they are doing and saying in the foreign language and that they also do it in Spanish. The effective, conscious use of the students' knowledge of their first language is a must in helping our monolingual children become good consecutive bilinguals; and a truly bilingual curriculum may be a much better way than what we know as bilingual education to work towards bilingualism at school in monolingual environments.

\section{References}

Ausubel, D.P. (1968). Educational psychology : A cognitive view. New York: Holt, Rinehart, and Winston.

Barriga-Villanueva, R. (2002). Estudios sobre el habla infantil en los años escolares: “...un solecito calientote”. México: El Colegio de México.

Barriga-Villanueva, R. (2003). Construyendo realidades: El lenguaje infantil de los años escolares. En Matute, E. y Leal, F (Eds.). Introducción al estudio del Español desde una perspectiva multidisciplinaria (pp. 183218). Guadalajara: Universidad de Guadalajara.

Brown, J., Collins, A. and Duguid, P. (1989). Situated Cognition and the Culture of Learning. Educational Researcher, 18 (1): 32-42.

De Mejía, A.M., Ordóñez, C. L. and Fonseca, L. (2006). Estudio investigativo sobre el estado actual de la educación bilingüe (inglés-español) en Colombia. Consulted on April 10, 2012 at http://www. colombiaaprende.edu.co/html/productos/1685/ articles-266111_archivo_1.pdf

Dewey, J. (1945). Experiencia y educación. (Lorenzo Luzuriaga, trad.). Buenos Aires: Editorial Losada S.A.

Dewey, J. (1948). El niño y el programa escolar. (L. Luzuriaga, Trad.). Buenos Aires: Editorial Losada.

Díaz Barriga, F. (2003). Cognición situada y estrategias para el aprendizaje significativo [on line]. Revista Electrónica de Investigación Educativa, 5 (2).
Consulted on May 22, 2010 at http://redie.ens.uabc. $\mathrm{mx} /$ vol5no2/contenido-arceo.html

Marinova-Todd, S., Marshall, B., \& Snow, C. (2000). Three misconceptions about age and second language learning. TESOL Quarterly, 1:9-34.

Ministerio de Educación Nacional. (2006). Formar en lenguas extranjeras: Inglés jel reto! Estándares básicos de competencias en lenguas extranjeras: Inglés. Bogotá D.C.: Imprenta Nacional.

Ninio, A., and Snow, C.E (1996). Pragmatic development. Boulder, Co: Westview Press.

Ordóñez, C.L. (2000). Oral bilingual proficiency of Colombian adolescents. Doctoral thesis not published, School of Education. Harvard University, Cambridge, MA.

Ordóñez, C.L. (2004). EFL and native Spanish in elite bilingual schools in Colombia: A first look at bilingual adolescent frog stories. International Journal of Bilingual Education and Bilingualism, Special Issue: Bilingual Education in South America, 7(5):449-474.

Ordóñez, C.L. (2005). Oral bilingual proficiency of Colombian adolescents in an elite bilingual school. In J. Cohen, K. McAllister, K. Rolstad, and J. MacSwan (eds.). ISB4: Proceedings of the Fourth International Symposium on Bilingualism (1765-1783). Somerville, MA: Cascadilla Press.

Ordóñez, C.L. (2008). Education for bilingualism in international languages in a monolingual sociolinguistic context. Lenguaje, 36 (2):353-384.

Ordóñez, C.L. (2010a). Desempeño auténtico en educación. En Pedagogía y didáctica: Texto del docente (151-160). Quito: Ministerio de Educación de Ecuador.

Ordóñez, C.L. (2010b). Educación para el bilingüismo en contexto monolingüe: dos lenguas conectadas desde el currículo. Estudios de lingüística inglesa aplicada ELIA, 10:41 - 76.

Ordóñez, C.L. (2011). Education for Bilingualism: Connecting Spanish and English from the Curriculum, into the Classroom, and Beyond. PROFILE 13(2):147 $-161$.

Perkins, D. (1998). What is understanding? in M. StoneWiske (ed.). Teaching for understanding: Linking research with practice (39-57). San Francisco: Jossey-Bass Publishers.

Piaget, J. (1970). Piaget's theory. In P. H. Mussen (ed.), Carmichael's manual of child psychology (Vol. 1). New York: Wiley. 
Snow, C.E. (2007). Determinants of the outcomes of language education: Developmental and sociolinguistic factors. In Memorias del segundo simposio latinoamericano de bilingüismo y educación bilingüe en América Latina (2-12). Bogotá: Ediciones Uniandes.

Van Lier, L. (2005). Interaction in the language curriculum: Awareness, autonomy, and authenticity. London: Longman.
Vygotsky, L. (1978). Mind in society. Cambridge, MA.: Harvard University Press.

Widdowson, H. G. (1978). Teaching language as communication. Oxford: Oxford University Press.

\section{THE AUTHORS}

CLAUDIA LUCIA ORDOÑEZ, holds a M.A. degree in Applied Liguistics, from Universidad de los Andes, Bogotá and a Master and Doctor of Education degrees from Harvard University. Her research concentrates on the area of cognitive and linguistic development and education. She is the director of the research group "De las concepciones a las prácticas pedagógicas"

DIANA CAROLINA GUEVARA, holds a degree in Philology and Foreign Languages from Universidad Nacional de Colombia. Currently, an English teacher at the second language program at Universidad Nacional de Colombia. She has participated as a research assistant in the group on bilingual education at Universidad Nacional de Colombia. 